\title{
SOSIALISASI PEMAHAMAN BISNIS PADA UMKM DI KECAMATAN PAMULANG
}

\author{
Haya Aqila Fauziah ${ }^{1)}$, Ike Nursafitri' ${ }^{2)}$, Bustomi $^{3)}$, Khairunisa $^{4)}$ \\ ${ }^{1,2,3,4}$ Program Studi Teknik Industri, Fakultas Teknik, Universitas Pamulang
}

\begin{abstract}
Abstrak
Pandemi yang terjadi sangat berdampak pada usaha kecil menengah maupun usaha-usaha dengan modal yang besar, pemutusan hubungan kerja, pasaran produk yang menurun drastis, di berlakukan nya PSBB oleh pemerintah yang membatasi ruang lingkup interaksi dengan pembeli, menjadi alasan yang tepat untuk mengadakan pengabdian kepada masyarakat dengan berkolaborasi antara Universitas Pamulang Program Studi Teknik Industri bersama pihak UMKM Kecamatan Pamulang. Metode pengabdian yang dilakukan adalah pemberian penyuluhan dan pendampingan yang dinilai lebih efektif guna menjadi arahan serta dapat di implementasikan langsung oleh para pelaku usaha. Hasil pengabdian berjalan dengan baik dalam situasi Pandemi Covid-19 dengan tetap memberlakukan Physical distancing dan memiliki antusias yang cukup oleh UMKM kecamatan Pamulang. Dengan pengarahan tentang konsep luas berwirausaha sehingga dapat menjadi solusi inovatif dikala pandemi covid-19.
\end{abstract}

Kata kunci : UMKM, Pengarahan, Kewirausahaan

\begin{abstract}
The pandemic that occurred greatly impacted small and medium-sized businesses and businesses with large capital, termination of employment, the product market has dropped dramatically, the implementation of the PSBB by the government which limits the scope of interaction with buyers, is the right reason to provide service to community by collaborating between the Pamulang University Industrial Engineering Study Program and the Pamulang District UMKM. The service method used is the provision of counseling and mentoring which is considered more effective in order to become direction and can be implemented directly by business actors. The results of this service went well in the Covid-19 Pandemic situation by still applying physical distancing and having sufficient enthusiasm by the Pamulang sub-district MSMEs. With a briefing on the broad concept of entrepreneurship so that it can be an innovative solution during the Covid-19 pandemic.
\end{abstract}

Keywords: UMKM, Direction, Entrepreneurship

Correspondence author: Khairunisa,dosen00743@unpam.ac.id, South Tangerang, Indonesia 


\section{PENDAHULUAN}

Pandemi yang terjadi selama setahun terakhir ini menyebabkan lumpuhnya perekonomian, baik dari industri besar sampai dengan industri kecil dan menengah, dari berbagai aspek kehidupan masyarakat yang mulai menurun dengan cepat akibat dari pemutusan hubungan kerja oleh perusahaan yang dilakukan guna mempertahankan kelangsungan perusahaan itu sendiri.

Hal ini dikarenakan proses stimulasi penanganan Covid-19 yang masih belum terlaksana dengan baik, akibat banyaknya pelanggaran yang terjadi dimasyarakat menyebabkan "macetnya" program pemerintah dalam penanganan pandemic covid-19 di Indonesia. Sehingga memperburuk kondisi para usahawan yang terus kehilangan "pasar", presentase mati nya industri kecil menengah tidak dapat lagi di elakkan, bahkan bagi industri besar pun menjadi pemicu pemutusan hubungan kerja secara besar besaran.

Isu UMKM menjadi topik utama dalam pembahasan ini dimana pengembangan UMKM secara besar-besaran dilakukan guna menaikkan taraf perekonomian Negara yang mulanya sangat terpuruk. Pelatihan dan pengarahan baik dari pemerintah sampai dengan para pelaku pendidik yang sekiranya menguasai ilmu tentang kewirausahaan terus digembar-gemborkan dari beberapa bulan belakangan ini, guna menarik perhatian serta menanamkan semangat berwirausaha yang sebelumnya mulai tumpul dimasyarakat. Tetapi sebenarnya dari pandemi yang terjadi ini merupakan sebuah peluang bagi para pelaku industri itu sendiri yang mana pemberlakukan industry 4.O yang sedang di galakkan secara tidak langsung diterapkan dalam kehidupan masyarakat.

Pendekatan kewirausahaan dapat diimplementasikan sebagai upaya membangun pondasi ekonomi. Kewirausahaan tidak saja melekat kretivitas dan inovasi, akan tetapi memiliki fungsi yang bersifat multidimensi, yaitu dianggap berperan mendukung sumber-sumber ekonomi, mulai dari ekonomi individu, ekonomi keluarga, pendapatan daerah, sampai meliputi penerimaan Negara(Aulia Rahmi, Ismanto, and Zainuddin Fathoni 2020) industri yang menjadi perhatian kali ini memanglah industri kecil dengan basis yang tidak begitu besar, untuk mengenalkan pasar konsumen dengan kendala kendala yang banyak terjadi membuat pengabdian kepada masyarakat ini mendapat antusias yang cukup.

Adapun pelaksanaan kegiatan PKM ini guna membahas upaya-upaya yang harus dilakukan UMKM agar menghasilkan pundi-pundi dengan cepat. Khususnya di daerah Pamulang dan sekitarnya yang dirangkup dalam komunitas sahabat UMKM Tangerang Selatan dengan melibatkan kolaborasi perguruan tinggi, khususnya dosen dan mahasiswa serta didukung oleh pihak Kecamatan Pamulang sinergitas antara masyarakat, akademisi serta pemerintah local dapat menciptakan peluang-peluang baru melalui proses coaching ini.

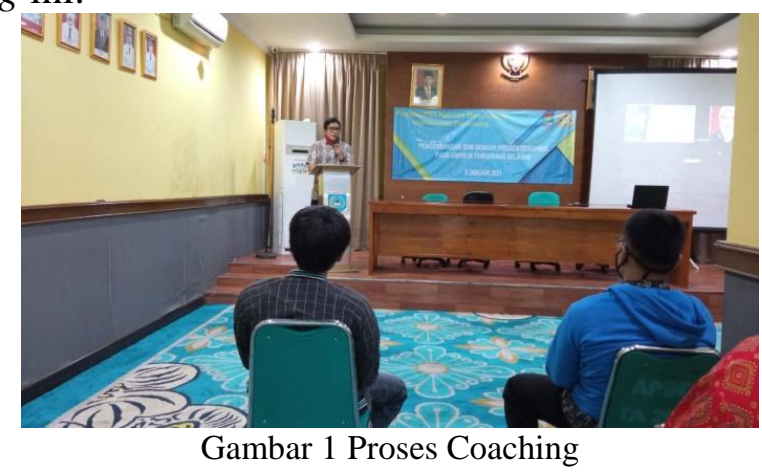


Upaya-upaya strategi yang harus dilakukan dalam pengembangan UMKM merupakan suatu upaya yang dilakukan rangka memajukan, memperbaiki, meningkatkan sesuatu yang sudah ada secara teratur dan bertahap agar menjadi lebih baik. Shingga menghasilkan pundi-pundi dengan cepat, dengan bisa membedakan 3 hal yaitu : Hidup,Penghidupan dan Kehidupan.

1). Hidup, Usaha yang dilakukan dalam mencukupi kebutuhan hidup itu salah satunya dengan mengembangkan UMKM dalam mengatasi keterbatasan akses permodalan kewirausahaan.

2). Penghidupan, dalam pengembangan usaha UMKM dengan meliputi: Pekerja Profesional dan Pengusaha yang dimana harus memiliki Kompetensi dalam memulai bisnis, Fashion, Great Konsisten menjalankan strategi pemasaran yang digunakan, dimana tujuannya adalah untuk membangun kepercayaan konsumen terhadap UMKM usaha tersebut. Kesungguhan dalam berbagai ide ,memiliki pengetahuan pada produk usaha yang dijalankan, memiliki Keterampilan/ Skill pada bidang bisnis yang ingin dimiliki. Penghidupan Sosial Selanjutnya sikap/mentalitas/attitude yang harus dimiliki sebagai seorang Pengusaha \& Pemikiran yang positif dalam membangun suatu usaha atau bisnis.

3). Kehidupan, memotivasi bahwa latar penghidupan untuk area bagaimana membawa untuk mencapai hal yang baik.

Para pelaku usaha harus memiliki wawasan serta informasi mengenai usaha atau bisnis UMKM yang dilakukan Yaitu Coaching Bisnis, yaitu Weakness (Kelemahan) yang diakibatkan faktor eksternal \& Ancaman pada produk internal kompotetor, Kekuatan produk pada bisnis yang dijalankan, Peluang yang luas untuk bisnis kedepannya. Penentuan Harga Pokok Penjualan UMKM, ialah menghindari dari kerugian, menentukan harga pokok penjualn dengan mengelist seluruh biaya yang dikeluarkan untuk bahan baku, dan kualitas produk usaha tersebut dengan begitu dapat menentukan Profit yang diinginkan, tetapi tetap dalam menentukan harga melihat harga Pasaran, apabila ingin menjual dengan harga lebih besar sebaiknya menambah nilai value (kelebihn pada produk yang dijual dengan pesaing).

Perihal sasaran yang dilakukan dari PKM kali ini adalah para pelaku usaha dibawah naungan sahabat UMKM Tangerang Selatan, para pelaku usaha ini dipandang lebih siap dalam menerima materi yang di berikan, selain itu peluang "goals" nya PKM ini jauh lebih besar dengan sasaran yang tepat, sehingga mampu meningkatkan kesejahteraan ekonomi (Bunsaman and Taftazani 2018)

Sasaran pelaksanaan kegiatan pengabdian kepada masyarakat dengan perguruan tinggi adalah sebagai berikut :

1). Berbagi pengalaman dan pengetahuan antara akademisi dengan pelaku usaha.

2). Membangun kerjasama dan sinergitas antara akademisi dengan komunitas UMKM TangSel.

3). Menemukan solusi terhadap permasalahan akibat dari covid-19.

4). Membangkitkan semangat berwirausaha di tengah keterpurukan di era pandemi ini.

Kegiatan pengabdian kepada masyarakat ini dilakukan dengan harapan bahwa para pelaku usaha khususnya sahabat umkm TangSel dapat menerima beberapa manfaat pelatihan dan pendampingan kewirausahaan, antara lain:

1). Menambah ilmu dan keterampilan mengenai pemasaran produk yang dapat meningkatkan nilai ekonomi dari produk tersebut.

2). Menyelamatkan perekonomian dari masyarakat 
3). Mengilhami prinsip kewirausahaan pada segala aspek kehidupan.

4). Mendukung program pemerintah dalam penanganan ekonomi ditengah pandemi covid-19

Agar tujuan dan manfaat dari kegiatan pengabdian mendapatkan hasil yang maksimal, maka dari tim perguruan tinggi program studi teknik industry menyediakan sarana prasarana dalam pelaksanaan pengabdian ini, serta terus dipantau menggunakan media elektronik secara berkala yang diharapkan mampu menjadi stimulan bagi para pelaku usaha untuk tetap berjuang di era covid-19 ini.

Keterlibatan perguruan tinggi sebagai penyedia wadah guna memberikan pengarahan terhadap para pelaku usaha akan menambah wawasan serta informasi baru yang memang harus diketahui dan diterapkan oleh para pelaku usaha yang notabennya merupakan masyarakat yang awam terhadap aturan serta kemajuan teknologi.

\section{METODE PELAKSANAAN}

Pengabdian kepada masyarakat bekerjasama dengan komunitas sahabat UMKM TangSel, Kecamatan Pamulang dilakukan dengan metode pertisipatif, edukatif, pendampingan dan evaluasi. Masing- masing metode tersebut secara teknis dapat diuraikan sebagai berikut:

1). Metode Partisipatif

Tahap pengabdian kepada masyarakat melibatkan koordinasi dengan pelaku UMKM secara personal, melakukan diskusi antara akademisi dengan pihak UMKM dalam rangka mengetahuii permasalahan para pelaku usaha dan memberikan solusi sebagai jalan keluar.

2). Metode Edukatif

Metode edukatif dilakukan dengan melakukan coaching kepada pelaku UMKM untuk memahami konsep dari kewirausahaan secara teoritis.

3). Metode Pendampingan

Pendampingan yang dilakukan kepada pelaku UMKM setelah kegiatan pengabdian ini bersifat peninjauan dengan menggunakan media elektronik. Tujuannya adalah memberi penguatan atas kendala kendala yang dihadapi oleh para pelaku UMKM.

Setiap masing masing metode yang dilaksanakan dilakukan secara berurutan, dengan system saling melengkapi antara kelebihan dan kekurangan setiap metode nya dan akan manjadi bahan evaluasi untuk kedepannya yang dinilai jauh lebih tepat digunakan.

\section{HASIL DAN PEMBAHASAN}

Kegiatan pengabdian kepada masyarakat dengan tujuan sebagai pengarahan dalam berwirausaha berbasis pengetahuan lanjutan mengenai pengolahan produk yang mengambil lokasi di Kecamatan Pamulang, Kabupaten Tangerang dengan melibatkan para pelaku UMKM yang terangkum dalam Sahabat UMKM Tangerang Selatan dalam rangka pemenuhan tri dharma perguruang tinggi sebagai akademisi, menjadi ujung tombak dalam melakukan gebrakan kewirausahaan. Secara keseluruhan pelaksanaan 
kegiatan berjalan dengan kondusif dan lancer. Pelaksanaan pengabdian dilakukan dengan menggunakan beberapa metode. Terdapat situasi dilapangan dimana terjadi keadaan yang meyebabkan beberapa perubahan pada pelaksanaanya.

Kondisi ini terkait dengan wabah covid-19 sehingga menerapkan protocol kesehatan "physical distancing" dilakukan, sehingga jumlah peserta yang megikuti kegiatan kali ini terbatas. Meski begitu hal ini tidak mengurangi atusiasme dari para pelaku UMKM, yaitu sahabat UMKM Tangerang Selatan dalam mengikuti acra pengabdian ini. Edukasi, pengarahan, dan pendampingan diterapkan guna mencapai hasil maksimal. Kegiatan edukasi merupakan aktivitas yang di berikan oleh akademisi untuk memberikan pemahaman atas konsep kewirausahaan, creativepreneur, dan legalitas nya. Edukasi diberikan sebagai pengetahuan teoritis kepada peserta pengabdian kali ini pada masing-masing bidang keilmuan.

Edukasi tidak hanya terpaku dengan pengabdian kali ini tetapi tetap dilakukan dengan saling berkounikasi menggunakan media social baik antara akademisi maupun antar pelaku usaha, guna meninjau penerapan dari pengabdian yang telah dilakukan serta berbagi informasi terkait situasi ekonominya. Pengetahuan akan kewirausahaan dan creativepreuner, akan menghasilkan pelaku usaha yang tahan banting akan banyak nya hambatan yang terjadi kedepannya.

Setelah menerima edukasi para pelaku usaha menerima pendampingan melalui media elektronik dari para akademisi, yang bertujuan untuk menjadi tindak lanjut atas pengabdian yang telah dilakukan, kerja sama antara akademisi, pemerintah, dan pelaku UMKM diharapkan dapat menjadi tonggak penunjang kehidupan masyarakat.

\section{SIMPULAN}

Secara keseluruhan kegiatan pengabdian kepada masyarakat ini berjalan lancar dan memiliki antusiasme yang baik oleh sahabat UMKM Tangerang Selatan dan pihak Kecamatan Pamulang selaku penyedia tempat. Hal - hal yang dapat disimpulkan mengenai hasil pengabdian kepada masyarakat ini sebagai berikut:

1). Tingginya minat dari para pelaku usaha guna mempertahankan usaha nya yang kian hari kian menurun akibat hilangnya pasar.

2). Terdapat perubahan pola pikir para pelaku usaha yang mulai memahami point point penting dalam berwirausaha di era pandemi covid-19 ini.

3). Sahabat UMKM TangSel memiliki inovasi baru terhadap produk yang mereka miliki

4). Antusiasme terhadap pematangan materi kepemimpinan dalam wirausaha lebih diminati dari pada creativepreneur.

Keberhasilan pengabdian kepada masyarakat ini merupakan hasil dari kolaborasi antara akademisi, Pemarintah dan pelaku usaha yang dapat dilihat melalui pengembangan produktivitas para pelaku usaha yang notabennya lebih kepada usaha kuliner, menajdi prospek bisnin yang menjanjikan. 


\section{DAFTAR PUSTAKA}

Aulia Rahmi, Vembri, Hadi Ismanto, and Muhammad Zainuddin Fathoni. (2020). Inovatif Saat Pandemi Covid Melalui Pelatihan Kewirausahaan Khas Perempuan Berbahan Sampah 'Kolaborasi BUMDes Dan Warga. Dinamisia: Jurnal $\begin{array}{llll}\text { Pengabdian } & \text { Kepada } & \text { Masyarakat } & 418-25 .\end{array}$ https://doi.org/10.31849/dinamisia.v4i3.4632.

Bunsaman, Shafila Mardiana, and Budi Muhammad Taftazani. (2018). Peranan Perempuan Dalam Meningkatkan Kesejahteraan Ekonomi Keluarga (Studi Tentang Peranan Petugas K3L Perempuan Universitas Padjadjaran Jatinangor (Zona: Rektorat)). Prosiding Penelitian Dan Pengabdian Kepada Masyarakat 5 (2): 146. https://doi.org/10.24198/jppm.v5i2.18373.

Suci, Yuli Rahmini. (2017). Perkembangan UMKM (Usaha Mikro Kecil Menengah) Di Indonesia. Jurnal Ilmiah Fakultasi Ekonomi. 